\title{
Women's economic autonomy during the COVID-19 pandemic
}

\author{
Nicole Bidegain, Lucía Scuro and Iliana Vaca Trigo
}

\begin{abstract}
This article is a contribution to the debate on the impacts of the COVID-19 crisis on gender inequalities in Latin America and the Caribbean, with a focus on women's economic autonomy. Through a review of the contributions of feminist economics and an analysis of the empirical evidence, it identifies a deterioration in the indicators associated with women's incomes and their participation in the labour market. The sexual division of labour is deepening in the region, endangering the scant progress made regarding women's economic autonomy in the pre-crisis years. It warns about gender biases in crisis mitigation policies and reflects on the importance of redistributing time, resources and power to move towards a new style of development based on gender equality and sustainability.
\end{abstract}

\section{Keywords}

Viruses, epidemics, economic aspects, feminism, women, income, labour market, women's employment, time, gender equality, Latin America and the Caribbean

\section{JEL classification}

B54, 054, D31, I38, J22

\section{Authors}

Nicole Bidegain is a Social Affairs officer in the Division for Gender Affairs of the Economic Commission for Latin America and the Caribbean (ECLAC). Email: nicole. bidegain@cepal.org.

Lucía Scuro is a Social Affairs officer in the Division for Gender Affairs of the Economic Commission for Latin America and the Caribbean (ECLAC). Email: lucia.scuro@cepal.org. lliana Vaca Trigo is a Statistician in the Division for Gender Affairs of the Economic Commission for Latin America and the Caribbean (ECLAC). Email: iliana.vaca-trigo@ cepal.org. 


\section{Introduction}

The COVID-19 pandemic in Latin America and the Caribbean has triggered multiple crises, and these have impacted men and women differently. The situation has showcased the structural nature of gender inequalities in the region and the greater exposure of women to the effects of crises. This pandemic arose in a context marked by asymmetries at the global level, low growth in the region's economies, deteriorating job quality and rising inequalities in countries with fragmented health systems, segmented labour markets and under-resourced gender equality policies. As in previous crises, women seem to be cushioning the impact by providing increased unpaid domestic and care work (ECLAC, 2020d and 2020f).

The recent literature agrees on the impact of the crisis for women, in both the developed world and developing countries and regions (United Nations, 2020). There are different approaches to the extent of the impact, to the factors that explain this phenomenon and to the dimensions of gender inequality being analysed, their intersection with other factors such as income, age and race and ethnicity, and their links with productive structures.

This article aims to contribute to the debate on the impact of the COVID-19 crisis on gender inequalities in Latin America and the Caribbean, with a focus on women's economic autonomy, and to identify some of the main underlying structural factors at play that must be attacked in order to avoid deepening gender inequalities in the medium and long terms. Section I reviews the literature on the main contributions of feminist economics to understanding the links between economic dynamics and gender inequalities, particularly at times of crisis. The following section analyses various indicators of women's economic autonomy based on the empirical evidence available from official sources and forecasts by the Economic Commission for Latin America and the Caribbean (ECLAC). Section III presents some thoughts on the approach to be adopted by mitigation and recovery measures in order to move towards a new style of development based on gender equality and sustainability.

\section{Crisis, feminist theory and COVID-19 in Latin America and the Caribbean}

Feminist economics, as a current of heterodox thought, has developed conceptual and methodological tools to understand how gender relations permeate the economic system and its dynamics, and these tools are useful in examining the externalities of the current crisis on women's lives and in proposing profound changes in the prevailing development model. In contrast to gender economics, feminist economics represents a transformative form of thinking, proposing a new paradigm that situates care work as a determining factor in social reproduction and in the population's living conditions (Picchio, 2005).

On the one hand, if offers an epistemological and methodological criticism of neoclassical theory on account of the androcentric bias implicit in the "representative agent", which attributes to the economic man (Homo economicus) characteristics that it considers universal but that, in reality, belong to a white, healthy, adult male human being of average income (Picchio, 2005; Rodríguez, 2015). The COVID-19 crisis highlights the fact that considerations such as gender, age, race and ethnicity place people in unequal positions of power for dealing with the pandemic and its related crises. The asymmetries of power that actors experience have repercussions on their probabilities of exposure to the virus, of securing access to quality health services, of enjoying a safe and violence-free domestic space, of having savings, of being able to engage in teleworking or distance education and so on. Therefore, the assumptions behind economic theories and policies should transcend homogenizing views of those actors in order to equip them with suitable instruments for responding to the multiple crises inherent in the pandemic through an approach that aims to close gaps. 
On the other hand, through conceptual tools and studies on gender, development and macroeconomics, it is possible to identify the implications of globalization processes and financial and fiscal policies for gender inequalities, particularly in crisis contexts. This area of knowledge production has also promoted frameworks of analysis to showcase the links between the macro, meso and micro levels of the economy (Elson, 1994), considering that men and women occupy asymmetrical positions of power as economic agents. Different studies analysing the policies implemented in developing countries and regions during the 1980s and 1990s have revealed that to a greater extent, women absorbed the costs of debt crises, structural adjustment programmes and public spending cuts, through an increase in care work and the greater precarity of their living conditions (Grown and Sen, 1987; Elson and Cagatay, 2000; Benería, Berik and Floro, 2015). Subsequent analyses examined the impacts of the 2007-2008 financial crisis and austerity policies (Elson, 2010; Montaño and Milosavljevic, 2012; Esquivel and Rodríguez, 2014; Fukuda-Parr, Heintz and Seguino, 2015; Bohoslavsky, 2018).

Elson (2010) proposes a framework for analysing the gender dimensions of the financial crisis in developing countries by examining economies as structures based on gender relations in the spheres of finance, production and social reproduction. It presents channels of transmission from the global North, the immediate impacts and the responses of governments, businesses and individuals in those three spheres. By analysing Argentina, Ecuador and Mexico, Esquivel and Rodríguez (2014) examine the impacts of the global economic crisis through the contraction of trade and the reduction of foreign direct investment and remittances and identify the repercussions on the activity, employment and incomes of men and women. Their analysis of the policy responses concludes that neither the design nor the impact assessments of the countercyclical policies adopted include considerations for addressing gender inequalities. The support provided for productive sectors and public investment was geared towards bolstering sectors where men are predominant, such as construction and infrastructure, and it did not explicitly include the creation of job opportunities for women as an objective. These analyses have been key in identifying the gender biases contained in the macroeconomic policy responses to different crises, and they are of relevance in the current context, when countries are launching fiscal stimulus packages.

Critical feminist economics has challenged orthodox and heterodox approaches to economics for their narrow definitions of the discipline that reduce it to the market economy. "The various economic approaches - whether more Keynesian or more neoliberal and despite the differences between themfocus exclusively on production, consumption and the distribution of goods and services, without considering labour and the many activities that fall outside the scope of the market. As a result, those analyses are not only partial but could also be erroneous. If only one part of the reality is taken into account and analysed but under the assumption that it forms the totality, there can be no assurance that the results - whether statistics or policies to be implemented - will be proper" (ECLAC, 2015, p. 13). The COVID-19 pandemic has served to showcase one of the main contributions of feminist economics: that the care work mainly performed by women within households is critical to the reproduction of the labour force and the functioning of economies (Picchio, 2001, 2005 and 2009)..$^{1}$ In that context, production relationships within households are made visible, where goods and services are produced to meet people's needs through unpaid work. Similarly, lockdown measures, physical distancing, the closure of schools and workplaces have increased this workload for women and deepened the care crisis (ECLAC, 2020d; ECLAC/UN-Women, 2020). In addition, the demands of education, the health care needs of sick people and the pressure to increase hygiene standards to prevent infection have been concentrated within households. In societies shaped by patriarchal and discriminatory cultural patterns, gender inequalities appear to be deepening.

\footnotetext{
1 As a reference, it should be noted that Picchio (2001, p. 1) defines the content of unpaid social reproduction work as "care of the maintenance of domestic spaces and goods, as well as care of bodies, education, training, maintenance of social relations and psychological support for family members".
} 
As a result of the COVID-19 crisis and the containment measures imposed worldwide, the boundaries between the public and private spheres have become blurred, further underscoring the interdependence between unpaid work and work for the market. Fully understanding this unprecedented phenomenon requires returning to the different contributions of feminist economics that have enabled the identification of distributive conflicts and gender power asymmetries within households and different types of families. Questions have been asked about the limitations of treating households as units of observation and the assumption that the household is a harmonious, conflict-free organization in which resources are equitably distributed among the members and where interests and "preferences" are reconciled to maximize benefits. ${ }^{2}$

Time-use measurements reveal the sexual division of labour and, in particular, the work overload faced by women, the differences between the types of tasks that men and women perform, the care arrangements that are established and the tensions between household members in reconciling paid and unpaid work. These elements are fundamental in analysing possibilities for labour market insertion, for teleworking and for accessing resources and own incomes. Attention should also be paid to household structures, family arrangements and the prevailing patriarchal cultural patterns.

The COVID-19 pandemic is revealing the importance of care work and calling into question one of the major androcentric biases of labour markets: the "ideal worker" model. That model assumes the "individual" as a person (man) who has no domestic and care responsibilities and who has the goods and services required for his well-being produced invisibly (Marçal, 2016; Picchio, 2001). He is a subject with plentiful time available for work in the market. This illusion has been shattered in the current context, which has evidenced the close interdependence between living conditions, health and care demands and availability for paid work.

One of the most important contributions to understanding the current crisis is the fact that feminist economics aims to expand the frontiers of the discipline of economics by placing the sustainability of life at the centre of the analysis. The central object of the economy should therefore be the provision of well-being, orienting its dynamics to sustain and reproduce human life in conditions of dignity (Carrasco, 2006 and 2009). The interdependence between people and their eco-dependence with nature and ecosystems highlighted by various authors (Carrasco and Tello, 2013; Pérez Orozco, 2014) is increasingly evident when analysing the causes and effects of the pandemic and the numerous crises associated with it. Those principles are key to reorienting economies' goals towards sustainability. From this more radical perspective within feminist economics, it can be seen that there are axes of domination that cannot be reduced to the conflict between capital and (paid) labour. There is a structural conflict between the process of capital accumulation and the sustainability of life, which obey opposing logics. Given the pre-eminence of accumulation, aspects of life and whole lives are treated as superfluous (Pérez Orozco, 2014). At this juncture, the conflict between capital and life manifests itself in different contexts and frames the policy decisions made by States in responding to the COVID-19 crisis. Therefore, the distributive question is central for feminist economics, but it must consider not only capital, but also resources, time and women in their diversity.

Within that framework, the concept of "the care economy" has been developed. This is understood to comprise all unpaid work carried out within households, as well as paid care work performed in the labour market. This concept covers care for the reproduction of the labour force in households, together with the dynamics of care in markets and employment, in the provision of public services and infrastructure and in the formulation of public policy. By relating the way societies organize the care of their members to the economic system, the concept of care can be linked to the economic value it generates (Montaño and Calderón, 2010).

\footnotetext{
2 See article on the contribution of Amartya Sen's conceptualization of cooperative conflicts to the conceptualization of negotiation models in the domestic unit (Benería, 2008).
} 
Although the impact of the COVID-19 crisis on women's economic autonomy is an ongoing phenomenon, the elements presented here provide background for research and conceptual tools for understanding the dynamics of the current crisis.

\section{Labour market, time and income: women's economic autonomy}

In Latin America and the Caribbean, gender inequalities are a structural element and they imply an unequal distribution of power, resources, wealth and time. The structural challenges of gender inequality are at the root of the unsustainability of the prevailing development model and they relate to socioeconomic inequality and the persistence of poverty, discriminatory and violent patriarchal cultural patterns and the predominance of the culture of privilege, the rigid sexual division of labour, the unjust social organization of care and the concentration of power. These challenges exacerbate each other and curtail the full enjoyment of women's rights and their progress towards substantive equality.

The reduction in income inequality attained over the last decade -through a combination of economic growth and progressive policies - did not produce a more balanced distribution between capital and (paid) labour. This asymmetry is exacerbated for women, who have less access to capital and are predominantly found in more precarious forms of paid work. Despite poverty reduction initiatives, there has been no decrease in the feminization of poverty, owing to the structural nature of gender inequality in the region (ECLAC, 2017).

The structural heterogeneity of the region's countries is reinforced by the current sexual division of labour, and therefore the interdependence between employment and unpaid work performed in the home must not be overlooked. This produces labour markets where employment is segregated by gender and where women have lower rates of participation in employment and are concentrated in economic sectors and occupations with weaker productivity, lower levels of income and limited access to social protection. The phenomena of vertical and horizontal gender segregation in the workplace and wage gaps are still common in current production structures that are not very diversified, make intensive use of natural resources, have low technological content and have major vulnerabilities associated with international asymmetries and external constraints. Barriers also persist in women's access to productive resources, such as credit, land, water, training, technologies and time (ECLAC, 2019).

Women are currently being affected by falling labour participation and heightened care demands. These impacts represent a reversal in the (albeit limited) progress made with the inclusion of women into the workforce. In recent decades, Latin America and the Caribbean recorded the world's largest percentage reduction in the labour participation gender gap, most of which occurred between 1997 and 2007 (7 percentage points). That trend was driven by a steady decline in the male participation rate combined with an increase in the proportion of women entering the workforce. Between 1997 and 2007, the female participation rate increased by 5.3 percentage points (Vaca Trigo, 2019). It has since continued to increase, albeit slowly, to an average of 51.3\% in 2019, 22.7 percentage points below that of men (ECLAC/ILO, 2020).

From a sectoral perspective, women are concentrated in activities such as commerce, tourism, manufacturing and the care economy (domestic service, health and education). The tourism, trade and manufacturing sectors are exposed to the external transmission channels of the crisis, such as the total or partial closure of borders, falling demand for tourism and the disruption of global value chains. In the context of the COVID-19 crisis, along with domestic service, those are exactly the sectors that faced the greatest losses in terms of output and employment. In Latin America, 56.9\% of female employment and $40.6 \%$ of male employment is concentrated in sectors facing high economic risks and the danger 
of job losses (ECLAC, 2020g). At the same time, while their jobs were not threatened, women employed in the health and education sectors had to provide the front-line response to the crisis by providing care work and preventing the spread of the virus while simultaneously increasing their working hours, exposing themselves to contagion or having to respond to the new demands of remote education.

In terms of labour market participation, the COVID-19 crisis differs from previous economic crises: in particular, significant numbers of both men and women withdrew from the region's workforce (see table 1). In previous crises, the economic contraction affected men and women differently, with an increase in women's labour participation while men were discouraged from working ${ }^{3}$ (ECLAC, 2014; Espino, 2012; Antonopoulos, 2009; Arroyo and others, 2010; Montaño and Milosavljevic, 2012). In the case of women, therefore, the "secondary worker" effect operates: those who enter the job market at times of crisis to increase the possibilities of securing an income for their families when male unemployment is running high (Esquivel and Rodríguez, 2014).

Table 1

Latin America and the Caribbean (14 countries): cumulative change in GDP during previous economic crises and during the COVID-19 pandemic, and variation in main labour market indicators by gender

(Percentages)

\begin{tabular}{|c|c|c|c|c|c|c|c|c|}
\hline & & \multirow{2}{*}{$\begin{array}{l}\text { Change in } \\
\text { GDP growth }\end{array}$} & \multicolumn{2}{|c|}{$\begin{array}{l}\text { Change in the labour } \\
\text { participation rate }\end{array}$} & \multicolumn{2}{|c|}{$\begin{array}{c}\text { Change in the } \\
\text { unemployment rate }\end{array}$} & \multicolumn{2}{|c|}{$\begin{array}{l}\text { Change in the } \\
\text { employment rate }\end{array}$} \\
\hline & & & Women & Men & Women & Men & Women & Men \\
\hline \multirow[t]{7}{*}{ Previous crises } & Brazil (1989-1990) & -4.4 & 1.0 & -1.1 & 3.7 & 20.2 & 0.8 & -1.1 \\
\hline & Argentina (2000-2002) & -14.8 & 2.5 & -1.8 & 9.7 & 30.4 & 0.5 & -6.5 \\
\hline & Uruguay (2000-2002) & -14.0 & 0.2 & -1.9 & 24.9 & 24.4 & -4.4 & -4.4 \\
\hline & Paraguay (2008-2009) & -4.0 & 2.5 & -0.2 & 7.6 & 26.8 & 1.9 & -1.5 \\
\hline & $\begin{array}{l}\text { Venezuela (Bolivarian } \\
\text { Republic of) (2008-2009) }\end{array}$ & -3.2 & 1.8 & -0.3 & 6.0 & 6.3 & 0.8 & -1.1 \\
\hline & & 2020 GDP & \multicolumn{2}{|c|}{$\begin{array}{l}\text { Change in the labour } \\
\text { participation rate }\end{array}$} & \multicolumn{2}{|c|}{$\begin{array}{c}\text { Change in the } \\
\text { unemployment rate }\end{array}$} & \multicolumn{2}{|c|}{$\begin{array}{c}\text { Change in the } \\
\text { employment rate }\end{array}$} \\
\hline & & & Women & Men & Women & Women & Men & Women \\
\hline \multirow[t]{13}{*}{ COVID-19 crisis } & Argentina & -9.1 & -8.7 & -12.2 & 2.3 & 2.6 & -8.7 & -12.4 \\
\hline & Bolivia (Plurinational State of) & -5.2 & -7.3 & -6.9 & 3.0 & 4.4 & -8.6 & -9.6 \\
\hline & Brazil & -9.2 & -7.1 & -6.2 & 0.8 & 1.7 & -6.5 & -6.7 \\
\hline & Chile & -7.9 & -9.0 & -7.2 & 11.7 & 9.4 & -12.9 & -12.8 \\
\hline & Colombia & -5.6 & -11.4 & -10.1 & 3.9 & 5.7 & -12.2 & -13.0 \\
\hline & Costa Rica & -5.5 & -6.2 & -4.6 & 15.4 & 10.1 & -12.1 & -11.3 \\
\hline & Dominican Republic & -5.3 & -8.8 & -7.9 & -5.2 & -1.8 & -5.7 & -6.3 \\
\hline & Jamaica & -5.3 & -4.3 & -3.5 & 3.8 & 5.7 & -5.9 & -7.1 \\
\hline & Mexico & -9.0 & -9.6 & -16.1 & -0.9 & 1.7 & -8.9 & -16.6 \\
\hline & Nicaragua & -8.3 & -4.6 & -3.3 & -0.5 & 0.4 & -4.1 & -3.4 \\
\hline & Paraguay & -2.3 & -6.3 & -2.5 & 1.0 & -0.5 & -6.4 & -2.0 \\
\hline & Peru & -13.0 & -28.4 & -24.9 & 3.5 & 6.4 & - & - \\
\hline & Uruguay & -5.0 & -3.6 & -3.8 & 0.6 & 1.2 & -3.6 & -4.3 \\
\hline
\end{tabular}

Source: Economic Commission for Latin America and the Caribbean (ECLAC), "Addressing the growing impact of COVID-19 with a view to reactivation with equality: new projections”, COVID-19 Special Report, No. 5, Santiago, 2020; Social Panorama of Latin America, 2014 (LC/G.2635-P), Santiago, 2014; Center for Distributive, Labor and Social Studies (CEDLAS); household surveys and official data from the respective countries.

a The variation in the main labour market indicators during past crises corresponds to the cumulative change for the periods indicated in ECLAC (2014). The figures for the COVID-19 crisis correspond to the year-on-year variation in the indicators between the second quarters of 2019 and 2020; the exceptions to this are Jamaica, where the data correspond to the year-on-year change between July 2019 and July 2020, and Mexico and Uruguay, which use the year-on-year change between May 2019 and May 2020.

3 Discouraged workers are those who are outside the workforce and who are not seeking employment for reasons linked to the labour market: e.g. previous failure to find a suitable job, lack of experience or qualifications, absence of jobs suited to the person's job skills, shortage of job vacancies in the area or the person is considered too young or too old by potential employers. 
It can be seen that during the second quarter of 2020, a higher proportion of women withdrew from the labour market than men. According to official figures from the region's countries for changes in employment levels between the second quarter (April to June) of 2020 and the corresponding period the previous year, women's employment recorded a greater contraction, reaching a figure of $45 \%$ in the case of Peru. In Chile, Colombia and Costa Rica, one in four women abandoned the job market compared to the corresponding quarter in 2019 (see figure 1).

Figure 1

Latin America (9 countries): change in the employed population, by sex, second quarter (April-June) 2020/2019

(Percentages)

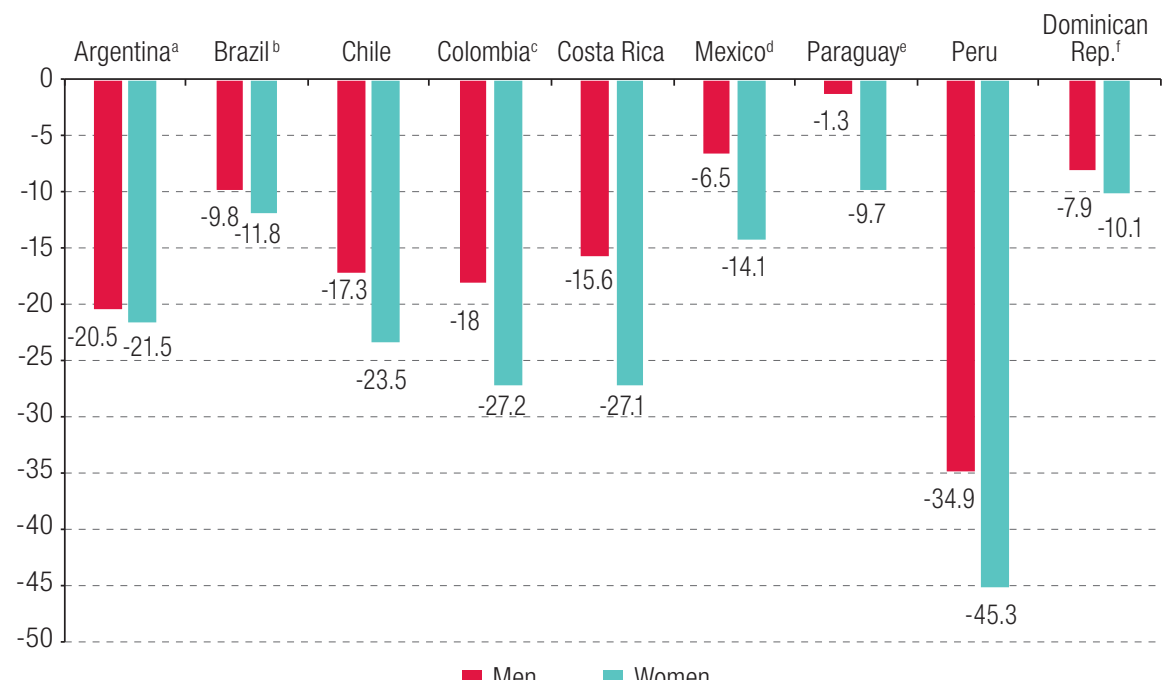

Source: Economic Commission for Latin America and the Caribbean (ECLAC), on the basis of National Institute of Statistics and Censuses (INDEC), Permanent Household Survey, Buenos Aires, 2020; Brazilian Institute of Geography and Statistics (IBGE), Continuous National Household Sample Survey - Continuous PNAD, Brasilia, 2020; National Institute of Statistics, Boletín estadístico: empleo trimestral, No. 261, Santiago, 2020; National Administrative Department of Statistics (DANE), "Boletín técnico: Gran Encuesta Integrada de Hogares (GEIH) junio 2020", Bogotá, 2020; National Institute of Statistics and Censuses, "Encuesta Continua de Empleo al segundo trimestre de 2020: resultados generales", San José, 2020; National Institute of Statistics and Geography (INEGI), National Survey of Occupation and Employment (ENOE) 2019, Aguascalientes, 2019; National Survey of Occupation and Employment (New Edition) (ENOEN) 2020, Aguascalientes, 2020; Department of Statistics, Surveys and Censuses, "Boletín trimestral de empleo: EPHC 2do trimestre 2020", Asunción, 2020; National Institute of Statistics and Informatics, "Comportamiento de los indicadores de mercado laboral a nivel nacional", Informe Técnico, No. 3, Lima, 2020; Central Bank of the Dominican Republic, Continuous National Survey of the Workforce, Santo Domingo, 2020

a Second quarter of 2020. Figures for 31 large conurbations.

b Second quarter of 2020, persons aged 14 and above employed in the reference week, by sex.

c National total does not include the population of the Departments of Amazonas, Arauca, Casanare, Guainía, Guaviare, Putumayo, Vaupés, Vichada and San Andrés.

d Data for Mexico refer to July 2019 and July 2020.

e Does not include the Departments of Boquerón and Alto Paraguay.

Quarterly data for April-June 2020. 2020 figures are preliminary data.

In recent years, the increased labour participation of women, together with a slower pace of job creation, has resulted in increased female unemployment, which remains higher than among men. In contrast to what usually happens during economic crises, the unemployment rate increased more for men than for women. This does not necessarily mean that men have been more affected by the crisis than women; instead, it underlines the need to complement labour market analyses based on the unemployment rate with the examination of other indicators relating to workforce participation and the distribution of unpaid work (ECLAC/ILO, 2020). In the current situation, there has also been a decline in women's economic participation rate: this was because many women, faced with loss of employment, 
the circumstances of the crisis and the high demand for care, did not to embark on the search for a new job. According to the latest estimates by ECLAC, women's labour market participation will contract by at least 6 percentage points regionwide (ECLAC, 2020h).

At the same time, the main source of income for both men and women $(65 \%$ and $67.2 \%$, respectively) is the remuneration of work through wages and salaries (see figure 2). This highlights the importance of wages in the composition of incomes in the region and, hence, the leading role of the labour market in economic autonomy and in cushioning the effects of crises. In addition to their predominance in income composition, wages and salaries also provide entitlement to various social benefits and rights if earned through formal employment.

Figure 2

Latin America (weighted average of 16 countries): income composition of people aged between 20 and 59, by sex and by income source and poverty, around 2019

(Percentages)

\section{A. Total population}

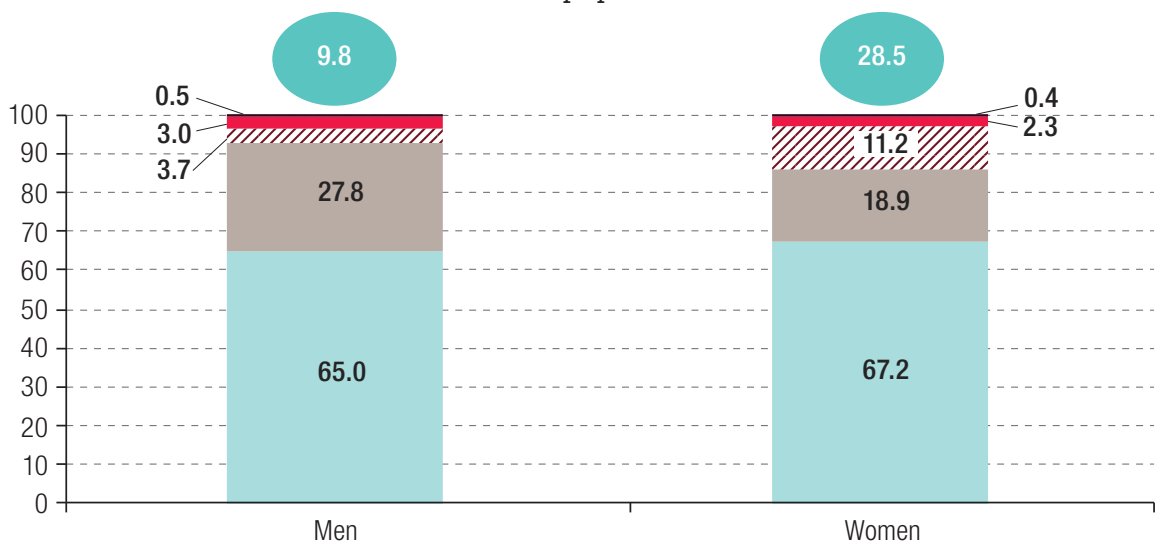

B. Population living in poverty

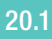

36.2

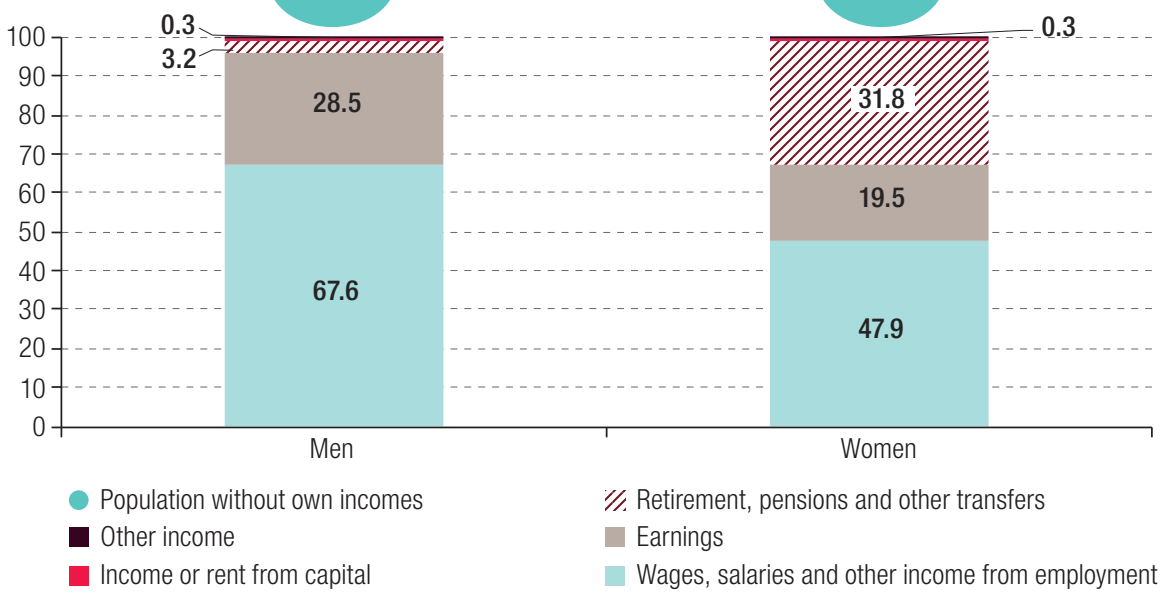

Source: Economic Commission for Latin America and the Caribbean (ECLAC), on the basis of special tabulations of data from household surveys conducted in the respective countries.

Note: People can receive incomes from a variety of sources: from insertion into the labour market in the form of wages and salaries or as earnings from self-employment, from income derived from the ownership of physical or financial assets and from transfers related to personal work histories or to any condition for which an individual receives money in a personal capacity. Transfers may come from the State, where they may be contributory (e.g. pensions) or non-contributory (e.g. disability pensions or special poverty alleviation programmes), or they may derive from a link with a family member or former family member in the form of remittances or obligations linked to marital dissolution. The data refer to 2019 para Argentina, Brazil, Costa Rica, Dominican Republic, Ecuador, El Salvador, Honduras, Panama, Paraguay, Peru and Uruguay; to 2018 for Colombia, Mexico and the Plurinational State of Bolivia; to 2017 for Chile; and to 2014 for Guatemala. 
Among men, the next third of their income comes from earnings, while for women that component accounts for $18.9 \%$ (see figure 2). In Latin America this type of income is associated not only with business undertakings and the management of financial assets - areas in which women have a lower presence - but also with the earnings from self-employment or own-account work: phenomena that are very widespread in the region, in both the formal and informal sectors, and in which women have a very strong presence. In this case, women's earnings can be more unstable and less protected, as they are strongly associated with informal work (ECLAC, 2016).

The Gender Equality Observatory for Latin America and the Caribbean (OIG) uses data on persons without their own incomes as a central element in examining women's autonomy and as an alternative for analysing individual resources without considering the household as a unit of analysis or assuming an equitable distribution of resources among all household members (ECLAC, 2020e). Among women aged between 20 and 59 in poor households, 36\% have no incomes of their own: hence, one in every three, which contrasts with the ratio of one in five found among the corresponding segment of the male population (see figure 2b).

Among men and women who do have their own incomes, there are marked differences in their composition. The most extreme case is transfers from the State. Identifying this difference in the sources of income is essential because of its strong link to the formulation of public policies to mitigate the current crisis. Transfers represent $11.2 \%$ of women's total incomes, compared to only $3.7 \%$ of men's (see figure 2).

An analysis of gender inequalities in poor households reveals that among women living in such conditions, transfers account for an average of $31.8 \%$ of their incomes, compared to only $3.2 \%$ of the incomes of men in a similar situation (see figure 2).

It should be noted that although more women than men receive transfers from programmes intended to fight poverty or mitigate the effects of economic crises, they cannot freely dispose of those funds: instead, they generally play the role of "managers" of resources assigned to the household under conditional transfer programmes. Women do not receive these resources as individuals in their own right but rather as operational beneficiaries, which reinforces their roles as "women-mothers" and as the main caregivers. The impact of conditional transfer programmes on women depends on such factors as the amount of the transfer, its coverage and the associated conditionalities. Recommendations have been made, however, to review the approach of these programmes, given that they reinforce the social maternalism of the policies, and even to assess eliminating conditionalities and promoting the principle of co-responsibility (ECLAC, 2016).

The general adoption of these social policy instruments, without adequate planning and scenarios for sustainable reconstruction and equality, poses the risk of distancing women from quality employment and universal social security policies (Montaño and Milosavljevic, 2012). In the current situation, when several of the region's countries have strengthened their transfer programmes, this notion is gaining importance as a way to avoid reproducing gender bias in public policy. Moreover, the criteria for ending this type of programme generally obey macroeconomic goals and indicators that do not necessarily take into consideration the difficulties women face in securing new sources of income of their own after the programmes end.

The health and economic crisis caused by the COVID-19 pandemic promotes the logic of targeted allocations of monetary resources without questioning those programmes' potential to perpetuate gender inequality if they are not examined in light of their gender-differentiated impacts. Although they are essential measures in the short term to cushion the fall in household incomes and mitigate increases in poverty, their design must incorporate additional measures for the medium and long terms since, if they are adopted as the only solution, mechanisms that may result in the worsening of gender gaps will be perpetuated. 


\section{Reflections for a transformative recovery}

The COVID-19 crisis has served to showcase the close interdependence between market-oriented economic processes and those of social reproduction. Given the absence of policies for the social redistribution of care and the persistence of patriarchal cultural patterns that translate into gender-differentiated expectations, women are absorbing the care overload and, consequently, are facing heightened barriers to their labour market participation.

This crisis is affecting women's levels of activity, employment and income and is increasing the precarity of their living conditions. A deterioration in the indicators associated with women's links to the labour market has been identified, most particularly a fall in their labour participation and their concentration in sectors exposed to loss of employment and incomes. As a result, the sexual division of labour is deepening and endangering the scant progress with women's economic autonomy made in the years prior to the crisis.

The region's governments have launched various initiatives to address the gender dimensions of the pandemic and its socioeconomic impact (ECLAC, 2020b). These measures have focused mainly on dealing with gender-based violence against women, protecting employment and incomes, providing access to benefits and transfers (with expanded coverage and amounts) and addressing various aspects of the care economy. So far, the actions seem to focus on measures to contain the short-term effects without the ability to transform inequality in the medium and long terms. To a lesser extent, the gender perspective has been incorporated into fiscal stimulus packages aimed at medium- and long-term reactivation, which would create more stable sources of income for women and boost their attainment of economic autonomy.

On occasions, the underlying approach of these policies reproduces gender biases by considering men as the households' main providers and women as workers with secondary incomes or primarily as caregivers. Measures are being adopted to protect the purchasing power of households without examining intra-household dynamics and under the assumption that resources are equitably distributed among family members.

At the same time, specific measures that consider women as a vulnerable population or a homogeneous group are part of a vision that perpetuates gender asymmetries and fails to address the structural causes of inequality. A rights-based approach is crucial for recognizing women's capacities to take their own decisions and States as the guarantors of their rights. In addition, such factors as age, income and race or ethnicity must be taken into account in determining women's exposure to the different socioeconomic impacts of the crisis and their ability to respond to them. It is therefore necessary to promote the design of short-, medium- and long-term policies with an intersectional approach that recognize the diversity of women and make real progress towards substantive equality.

The COVID-19 crisis should be an opportunity to trace out a new path in the region's development model that will help to overcome the structural challenges of gender inequality and advance towards full autonomy for women.

With this in mind, incorporating a gender perspective into macroeconomic, productive and social policies for the reactivation period is essential in transforming the economies. This requires not only the full incorporation of women into the recovery's strategic and driving sectors, ${ }^{4}$ but also profound changes in policy approaches, the distribution of power and time, resource allocation and economic incentives, basing the policy response on the principles of gender justice, sustainability and equality. This implies rethinking production, consumption and sustainable distribution patterns and reorienting finance towards the real economy. It also means advancing towards productive diversification in sectors strategic for

4 ECLAC (2020a) identifies the digital economy, health-sector manufacturing, sustainable tourism and others. 
the sustainability of life that will contribute to creating quality jobs, overcoming gender-based labour segregation and improving the social redistribution of care in line with the principle of co-responsibility.

What is needed is macroeconomic environment conducive to recovery with equality. The policy space of States to determine their policies must be respected so they can deploy tools to address the impact of the crisis in a way that guarantees women's rights and works to close structural gaps. Although the countries' fiscal space is limited, it can be expanded by increasing the progressiveness of tax systems, through direct taxes on income and wealth and by combating tax evasion, tax avoidance and illicit financial flows (ECLAC, 2019 and 2020a). The mobilization of additional public resources is necessary to strengthen the financing of gender equality policies in areas that are of strategic importance for women, such as care services, sexual and reproductive health and attending to gender-based violence. Proposals for fiscal austerity and procyclical policies under the assumption that the market is the most efficient allocator of resources will not help close inequality gaps. The recommendation is therefore the adoption of countercyclical fiscal policies that incorporate the gender perspective into their design in order to reverse the effects of the crisis on women's autonomy and promote a sustainable and transformative recovery that will allow substantive equality to be attained.

\section{Bibliography}

Antonopoulos, R. (2009), "The current economic and financial crisis: a gender perspective", Working Paper, No. 562, Annandale-On-Hudson, The Levy Economics Institute of Bard College, May.

Arroyo, L. and others (2010), "Los efectos de la crisis sobre las mujeres: empleo, segregación ocupacional y modelo productivo", Informes de la Fundación, No. 17, Madrid, $1^{\circ}$ de Mayo Foundation, March.

Benería, L. (2008), "De la 'armonía' a los 'conflictos cooperativos': la contribución de Amartya Sen a la teoría de la unidad doméstica", Araucaria, vol. 10, No. 20, Sevilla, University of Sevilla, October.

Benería, L., G. Berik and M. Floro (2015), Gender, Development and Globalization: Economics as if All People Mattered, Abingdon, Routledge.

Bohoslavsky, J. (2018), Report of the Independent Expert on the effects of foreign debt and other related international financial obligations of States on the full enjoyment of all human rights, particularly economic, social and cultural rights: impact of economic reforms and austerity measures on women's human rights (A/73/179), New York, United Nations, July.

Carrasco, C. (2009), "Mujeres, sostenibilidad y deuda social", Revista de Educación, Madrid, Ministry of Education, Culture and Sports.

(2006), "La economía feminista: una apuesta por otra economía", Estudios sobre género y economía, M. Vara (ed.), Madrid, Akal.

Carrasco, C. and E. Tello (2013), "Apuntes para una vida sostenible", Tejiendo alianzas para una vida sostenible: consumo crítico, feminismo y soberanía alimentaria, X. Montagut, C. Murias and L. Vega (coords.), Barcelona, Xarxa de Consum Solidari/World March of Women.

ECLAC (Economic Commission for Latin America and the Caribbean) (2020a), Building a New Future: Transformative Recovery with Equality and Sustainability (LC/SES.38/3-P/Rev.1), Santiago, October. (2020b), "Measures and actions at the national level", Santiago, COVID-19 Observatory in Latin America and the Caribbean [online] https://www.cepal.org/en/topics/covid-19.

(2020c), "Addressing the growing impact of COVID-19 with a view to reactivation with equality: new projections", COVID-19 Special Report, No. 5, Santiago, July.

(2020d), "The COVID-19 pandemic is exacerbating the care crisis in Latin America and the Caribbean", COVID-19 Report, Santiago, April.

_ (2020e), "People without incomes of their own", Santiago, Gender Equality Observatory for Latin America and the Caribbean [online] https://oig.cepal.org/en/indicators/people-without-incomes-their-own. (2020f), "Latin America and the Caribbean and the COVID-19 pandemic: economic and social effects", COVID-19 Special Report, No. 1, Santiago, April.

(2020g), "La autonomía económica de las mujeres en la recuperación sostenible y con igualdad", COVID-19 Special Report, Santiago, unpublished. 
(2020h), Balance Preliminary Overview of the Economies of Latin America and the Caribbean 2020 (LC/PUB.2020/17-P), Santiago.

(2019), Women's autonomy in changing economic scenarios (LC/CRM.14/3), Santiago, December.

(2017), Montevideo Strategy for Implementation of the Regional Gender Agenda within the Sustainable Development Framework by 2030 (LC/CRM.13/5), Santiago, March.

(2016), Equality and women's autonomy in the sustainable development agenda (LC/G.2686/Rev.1), Santiago, December.

(2015), Regional review and appraisal of implementation of the Beijing Declaration and Platform for Action and the outcome of the twenty-third special session of the General Assembly (2000) in Latin American and Caribbean countries (LC/L.3951), Santiago, February. (2014), Social Panorama of Latin America, 2014 (LC/G.2635-P), Santiago, December.

ECLAC/ILO (Economic Commission for Latin America and the Caribbean/International Labour Organization) (2020), "Employment trends in an unprecedented crisis: policy challenges", Employment Situation in Latin America and the Caribbean, No. 23 (LC/TS.2020/128), Santiago, November.

ECLAC/UN-Women (Economic Commission for Latin America and the Caribbean/United Nations Entity for Gender Equality and the Empowerment of Women) (2020), Care in Latin America and the Caribbean during the COVID-19: Towards comprehensive systems to strengthen response and recovery, Santiago, August.

Elson, D. (2010), "Gender and the global economic crisis in developing countries: a framework for analysis", Gender \& Development, vol. 18, No. 2, Abingdon, Taylor and Francis, July.

(1994), "Micro, meso, macro: gender and economic analysis in the context of policy reform", The Strategic Silence. Gender and Economic Policy, I. Bakker (ed.), London, Zed Press/North-South Institute.

Elson, D. and N. Cagatay (2000), "The social content of macroeconomic policies", World Development, vol. 28, No. 7, Amsterdam, Elsevier, July.

Espino, A. (2012), "La dimensión de género de la crisis ¿Existe una agenda feminista?”, Nueva Sociedad, No. 237, Buenos Aires, January-February.

Esquivel, V. and C. Rodríguez (2014), "Addressing the global economic crisis in Mexico, Ecuador and Argentina: implications for gender equality", Gender Perspectives and Gender Impacts of the Global Economic Crisis, R. Antonopoulos (ed.), New York, Routledge.

Fukuda-Parr, S., J. Heintz and S. Seguino (eds.) (2015), Critical and Feminist Perspectives on Financial and Economic Crises, London, Routledge, April.

Grown, C. and G. Sen (1987), Development, Crises and Alternative Visions: Third World Perspectives, New York, Monthly Review Press, December.

Marçal, K. (2016), ¿Quién le hacía la cena a Adam Smith? Una historia de las mujeres y la economía, Barcelona, Random House Mondadori, August.

Montaño, S. and C. Calderón (coords.) (2010), El cuidado en acción: entre el derecho y el trabajo, Cuadernos de la CEPAL, No. 94 (LC7G.2454-P), Santiago, Economic Commission for Latin America and the Caribbean (ECLAC), September.

Montaño, S. and V. Milosavljevic (2012), "The economic and financial crisis: its impact on poverty, work and women's time", Women and Development series, No. 98 (LC/L.3168-P), Santiago, Economic Commission for Latin America and the Caribbean (ECLAC), May.

Pérez Orozco, A. (2014), Subversión feminista de la economía: aportes para un debate sobre el conflicto capital-vida, Madrid, Traficantes de Sueños, May.

Picchio, A. (2009), "Condiciones de vida: perspectivas, análisis económico y políticas públicas", Revista de Economía Crítica, No. 7, Valladolid, Association of Critical Economics.

- (2005), "La economía política y la investigación sobre las condiciones de vida", Por una economía sobre la vida: aportaciones desde un enfoque feminista, G. Cairó and M. Mayordomo (coords.), Barcelona, Icaria Editorial.

(2001), "Un enfoque macroeconómico ‘ampliado' de las condiciones de vida”, Tiempos, trabajo y género, Barcelona, University of Barcelona.

Rodríguez, C. (2015), "Economía feminista y economía del cuidado: aportes conceptuales para el estudio de la desigualdad", Nueva Sociedad, No. 256, Buenos Aires, March-April.

United Nations (2020), Policy Brief: the impact of COVID-19 on Latin America and the Caribbean, New York, July. Vaca Trigo, I. (2019), "Oportunidades y desafíos para la autonomía de las mujeres en el futuro escenario del trabajo", Gender Affairs series, No. 154 (LC/TS.2019/3), Santiago, Economic Commission for Latin America and the Caribbean (ECLAC), January. 